\title{
Grey Seal Studies on North Rona
}

$$
\text { By J. Morton Boyd }
$$

For eight years the Nature Conservancy has been studying the grey seals on the island reserve of North Rona to get the necessary facts for a grey seal conservation policy. The programme involves an annual visit to this most remote British island each October to count and mark the pups. The author, who is in charge of the programme, describes the methods used and the results so far, but it is still not known, for instance, whether seals born on North Rona return there to breed, and if not, where they do go.

THE Nature Conservancy's eighth annual expedition to count, brand and make routine observations on the breeding assembly of grey seals Halichoerus grypus on North Rona took place from October 24th to 31st, 1966. These annual expeditions are part of a continuous programme of research on the grey seals in this National Nature Reserve. North Rona is an island of 300 acres some 45 miles north-west of Cape Wrath, and one of the most inaccessible of the British Isles. Inhabited until 1844, and again in 1885 when two men from Lewis went to live there but died during their first winter, the only buildings on the island are the ruins of a village of semi-underground dwellings, and a chapel and cell. The cell dates to the immediate post-Columban period, the eighth or ninth century $A \mathbf{D}$, when a monk, later called St. Ronan, lived on the island. The chapel was built on to the cell about the 12th century. The buildings were probably roofed and in use until permanent occupation ceased in 1844.

None of the old records of North Rona ${ }^{1,2,3}$ mentions seals, and it seems certain that the present colony started with the end of human settlement. An almost exact parallel occurred more recently at St. Kilda. When the human population left St. Kilda in 1930 there were no breeding seals there, and indeed few seals at any time of the year; but when the RAF set up the present military installations in 1956 they found seals breeding, and large numbers present all the year round ${ }^{4}$. By the beginning of this century North Rona had probably become one of the main breeding stations of the grey seal in Britain. It may have been colonised from Sula Sgeir, where Lewismen hunted them, and from Sule Skerry where Orcadians hunted them and whence the colony departed following the building of the lighthouse in 1895, but it was not until Dr. F. Fraser Darling went to spend the autumn of 1938 on Rona that the approximate size of the colony became known ${ }^{5}$. Dr Darling's visit was unfortunately frustrated by the Munich crisis, and his plans for return by the war; it was only in 1959 that it was followed up by the first Nature Conservancy expedition. 
The North Rona and Sula Sgeir Reserve, now ten years old, was set up primarily to protect the grey seals and their breeding grounds from any damaging interference by man, and to promote research into the population ecology of the animals and the techniques of breeding-ground management. If conservation is to be effective, the size, geographical distribution and recruitment of breeding animals to the colony must be ascertained as soon as possible. Each autumn a party of four men with food and other equipment is taken to the island by a fishery cruiser of the Royal Navy and put ashore at one of several landing places, all difficult. The party, based in one of the semi-underground houses, temporarily roofed over with tarpaulins and out of sight and scent of the seals, then spends from a week to a month on the island, depending on the working programme and the weather, before being taken off again by the fishery cruiser.

The number of pups born annually on North Rona is the only measure of the size of the assembly which can readily be obtained. Pups are born between mid-August and mid-December, but by far the largest number are born in October with the peak of the pupping about the 12th. Unless counts are made at intervals of a few days throughout the entire period it is not possible to obtain an absolute measure, and the disturbance which this would cause might substantially affect the result. In 1959 a mean daily birth-rate curve was obtained over a period of 21 days in October ${ }^{8}$. Against this, subsequent expeditions of shorter duration, when only two counts were obtained, have been able to check their figures; only one count was done in 1966 , on October 27th. Fig. 1 shows the annual index of seal pups arrived at by this method; it is a measure of minimum assembly size since after October 20th unknown numbers of sea-going pups leave the island and escape the late counts.

The causes of fluctuations of this index are unknown; they may result partly from variations in the survey method and partly from prevailing ecological factors. Failure to produce pups in any year may be due to events in the previous year, e.g. disturbance by the survey party resulting in fewer conceptions, or to those of several years previous, affecting recruitment of new breeders. No downward trend is, however, apparent, although the 1965 and 1966 totals are the lowest so far.

The mortality of young pups at North Rona is high, ranging from 15 to 25 per cent. of the total pups present on census days in October. In localities such as the gullies of the Fianuis promontory, which are narrow busy access routes between the sea and the nursery, mortality may be as high as 38 per cent.; in others, such as the colony on the ridge some 250 feet above sea level, where the adults are few and well-spaced, dead pups are rarely found.

Coulson and Hickling ${ }^{7}$ listed the causes of grey seal pup deaths on the Farne Islands as starvation, still births and accidents at birth, injuries caused by other seals, infection and misadventure. Starvation causes the greatest number of deaths on the Farnes, and this depends 




Fig. 1. Total numbers of pups born annually on North Rona, estimated from the mean daily birth-rate curve of 1959, and counts of pups in late October, and annually thereafter.

to a great extent on human disturbance. It is often difficult to determine the primary cause of death since injury may result in starvation, and vice versa. On Rona the reaction of the cows to man varies widely; when their pups are taken away from them for a short time for branding their behaviour ranges from total desertion at first sight to what, if carried to a conclusion, might be a fight to the death. The proportion of pups on Rona which die of starvation is probably high, but large numbers are also fatally injured; all other causes of death are minor.

Many young pups die after being crushed or bitten by adults, especially when the colony is disturbed. Breeding grounds differ in lay-out, some, like the Treshnish Isles ${ }^{8}$, are linear, stretching along the shore; others, like some of the Farnes and Rona, are extensive, occupying large areas, and disturbance differs according to the lay-out. In linear grounds adults can pass directly from sea to breeding territory, but in extensive grounds, such as Rona, they must pass through or round densely occupied and intensely contested ground to reach suitable breeding sites. Each intruder sets up a wave of unrest, followed by fights between territorial bulls and jealous cows with almost total disregard for pups.

Human presence is enough to keep a colony in a state of unrest, and the sudden appearance of a man can stampede the adults, causing fatal injuries to pups. A study has been done on Rona to find ways in which the main concentrations of seals can be observed with 




Fig. 2. The positions and cyphers of brands used on young grey seals at North Rona between 1960 and 1965.

minimum disturbance, but it has to be recognised that census and branding operations are major forms of disturbance, even when, as here, they are only done at well spaced intervals and in such a way as to cause minimum threat to young pups.

Smith ${ }^{9}$ studied in detail the effects of human interference in Orcadian and Hebridean colonies, and made a useful classification of different kinds of interference, from long range casual contact to mass slaughter; he also made observations on the recovery of colonies after large-scale disturbance. No seals are killed on Rona (though occasional visits by foreign sealers to kill adults in the sea is suspected), and intense disruption of the colony is limited to a week in late October; for the remaining six weeks of the breeding season there is evidence of little or no disturbance. Fishermen occasionally go ashore, but without obvious harm to the seals.

The distribution study started with a marking programme. In 1959, 1960 , and 1961 pups were tagged on the hind flippers or the tail; the flipper tags (1959) were successful in providing one recovery, but the tail tags (1960/61) stayed on the animals long enough to allow observations of the scatter of young seals from North Rona in the first two years of life. The oldest seal to be recovered wearing a North Rona tag was taken in a trawl net in the North Sea at the age of 23 months. Yearling seals from Rona have been recovered as far apart as western Ireland, eastern Iceland and southern Norway ${ }^{10}$. Tagging was abandoned after 1961, but the branding programme 


$\begin{array}{lcccc}\text { Year } & \begin{array}{c}\text { Day in } \\ \text { October }\end{array} & \begin{array}{c}\text { Total pups } \\ \text { Dead pups }\end{array} & \% \text { Dead } \\ 1959 & \text { 20th } & 1,737 & 295 & 17 \\ 1959 & \text { 24th } & 1,899 & 323 & 17 \\ 1960 & \text { 20th } & 1,696 & 352 & 21 \\ 1960 & \text { 28th } & 1,691 & 402 & 23 \\ 1961 & 17 \text { th } & 1,803 & 457 & 25 \\ 1962 & \text { 8th } & 1,120 & 170 & 15 \\ 1962 & \text { 16th } & 1,400 & 289 & 21 \\ 1963 & 27 \text { th } & 2,147 & 305 & 14 \\ 1963 & \text { 31st } & 2,020 & 305 & 15 \\ 1964 & \text { 13th } & 1,773 & 282 & 16 \\ 1964 & \text { 17th } & 1,882 & 324 & 18 \\ 1965 & \text { 24th } & 1,597 & 351 & 22 \\ 1966 & \text { 27th } & 1,684 & 347 & 21\end{array}$

started in 1960 continues, and nearly 3,800 pups have been branded, including 600 (287 males, 313 females) done in 1966. Apart from branded yearlings seen at North Rona, records of brands have come from dealers in the fur trade, one has been reported from Cullen, Banffshire, and another from just north of Bergen in Norway. A section of the skin from the Cullen pup was sent in for examination; the brand was well healed and there was no sign of infection. The Norwegian pup was caught in a set net and had fish in its stomach. Both were branded at Rona in late October, 1966, and reported from the two sites in late November, about four weeks later. So far there have been 27 recaptures or sightings out of some 3,800 marked. The siting of brand marks is shown in Fig. 2.

Only pups which are over three weeks old are selected for branding. The majority of those have been weaned, have cast thir infant coat, are over 100 pounds in weight ( 30 pounds at birth) and are ready for the sea. The animals do not react to the brand, which is only applied for a second or two, and the blubber seems to deaden any effect. Sightings of year-old brand marks and recoveries of brands taken from animals which have been shot soon after branding show the brands to have healed perfectly and to provide a very clear means of identification.

Do North Rona seals return to Rona to breed, or do they go elsewhere and in what numbers? These are questions still to be answered and of the utmost importance for the conservation of the grey seal throughout its range, particularly when it comes to fixing culling levels. The input of numbers into an assembly may not be determined by the pup production of that assembly alone, but also by the recruitment of breeding animals born elsewhere. A search for branded seals in breeding assemblies in future years will throw a great deal of light on this vitally important point; the first cows, branded in 1960/61, will be making their appearance on the breeding grounds in 1966/67 and the bulls possibly in 1969/70; none have so far been observed on Rona. Any information about sightings of branded seals will be 
gratefully received and acknowledged by the Regional Officer, West Scotland, The Nature Conservancy, 12, Hope Terrace, Edinburgh 9. A reward of $£ 1$ is now being offered for information on the recapture of seals branded at North Rona.

\section{REFERENCES}

1. MONRO, D. (1884), Description of the Western Isles of Scotland (circa 1549). Glasgow, T. D. Morrison.

2. MARTIN, M. (1703), A Description of the Western Islands of Scotland. London.

3. MACCULLOCH, J. (1824), The Highlands and Western Isles of Scotland. London.

4. WILliAMSON, K. and BOYD, J. M. (1963), A Mosaic of Islands. Edinburgh, Oliver and Boyd.

5. DARLING, F. F. (1939), A Naturalist on Rona. Oxford, Clarendon Press.

6. BOYD, J. M., HEWER, H. R. and LOCKIE, J. D. (1962), The breeding colony of grey seals on North Rona, 1959. Proc. Zool. Soc. Lond. $138: 257-77$.

7. COULSON, J. C. and HICKLING, G. (1964), Breeding biology of the Grey Seal, Halichoerus grypus (Fab.), on the Farne Islands, Northumberland, J. Anim. Ecol, 33:485-512.

8. DARLING, F. F. and BOYD, J. M. (1964), The Highlands and Islands. London, Collins.

9. SMITH, E. A. (1964), The effects of human interference in a grey seal breeding colony and the phenomenon of fostering. Proceedings of a Seal Symposium, Cambridge, 9th September 1964, Nature Conservancy, London (mimeographed).

10. BOYD, J. M. (1964), The grey seal (Halichoerus grypus Fab.), in the Outer Hebrides in October 1961. Proc. Zool. Soc. Lond., 141:635-61.

crest along the back, the long hair on the neck and, of course, the appearance of rudimentary horns.

Early writers refer to nyala as being extremely shy and very difficult to find, and this used to be the case in Malawi. However, after only three years of full protection, this beautiful animal has become far less shy than most others in the Lengwe reserve, certainly less so than its nearest relatives, kudu and bushbuck. It is now unusual not to find a number of nyala standing within a short distance of the road up to about 8 o'clock in the morning and again in the late afternoon, and, given the right wind conditions, the water-hole seldom fails to produce a number, particularly around midday. The record so far was on August 19th, 1966, when a mixed herd of thirty-two, including several large males, were seen together. 

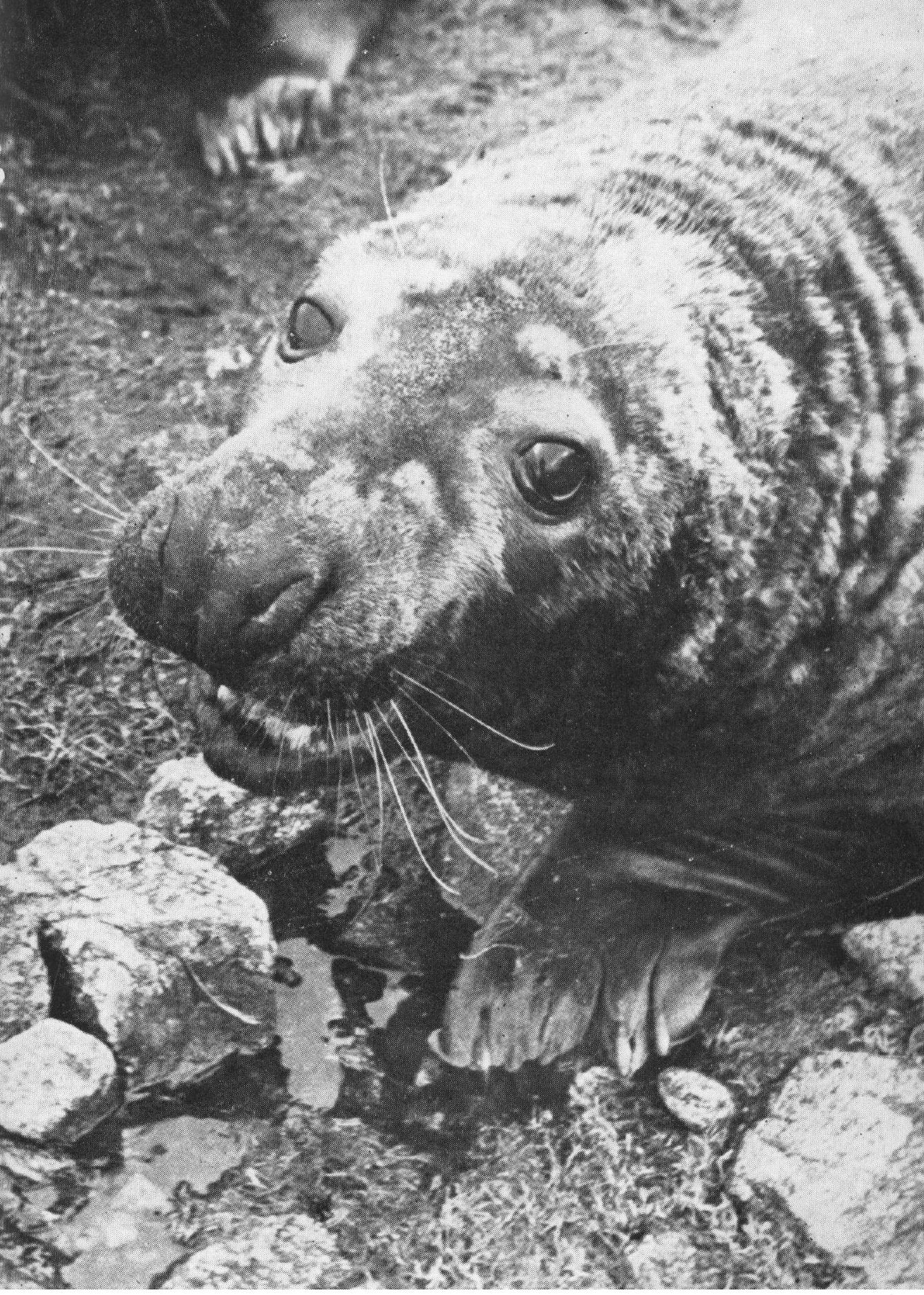

GREY SEALS ON NORTH RONA

J. Morton Boyd





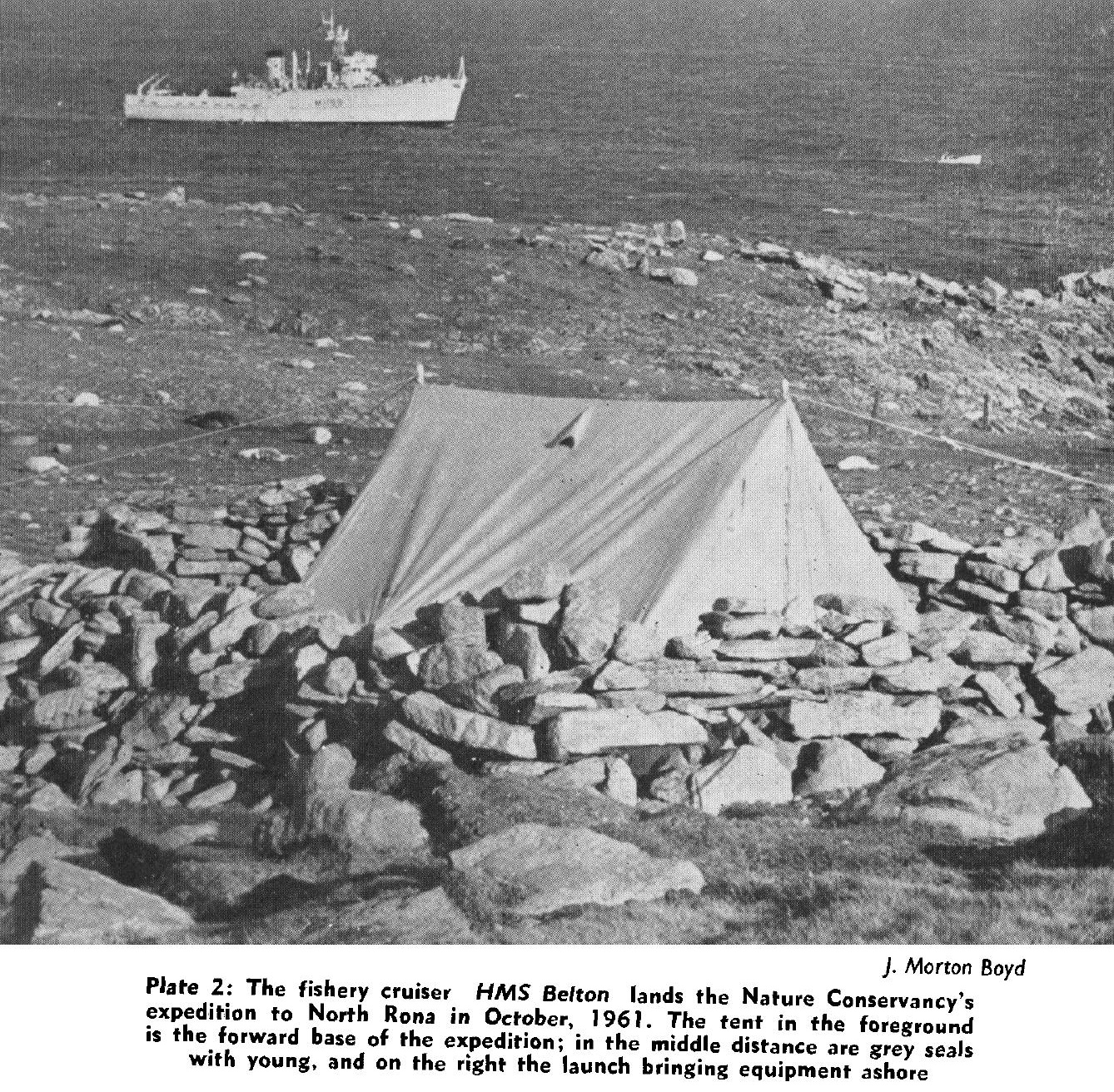


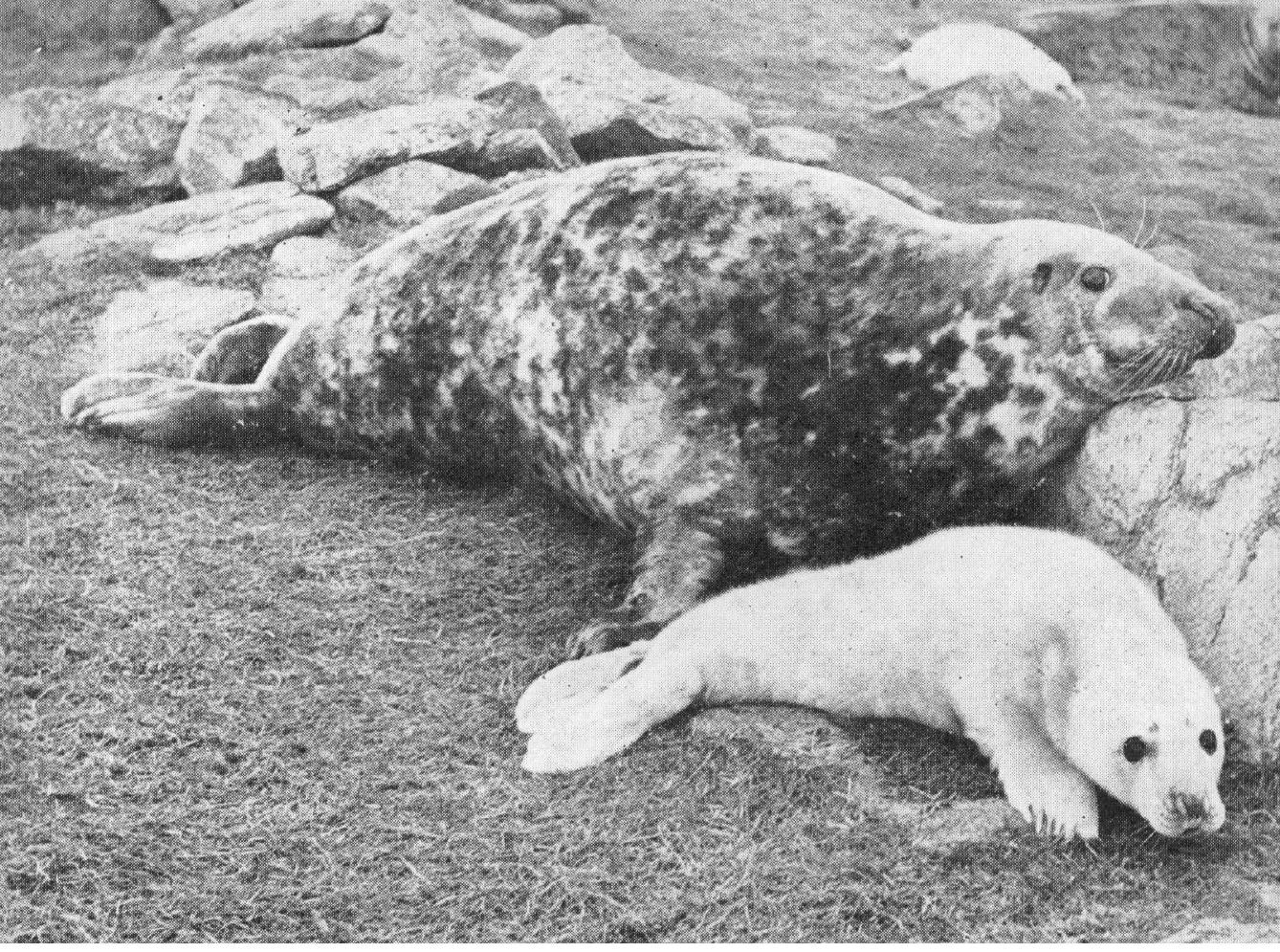

Plate 3: Cow with a week-old pup in infant coat. The tapering form of the pup is in marked contrast with the plump three-week-old one in the background. Well-fed pups put on more than three pounds weight a day

\section{GREY SEAL PUPS ON NORTH RONA}

Photographs by R. Tweddle

Plate 4: A month-old pup moulting its infant coat and showing the ' $Y$ ' brand mark on the left flank








Plate 5: A group of nyala at the waterhole that was sunk on the direct orders of Dr. Banda, and which has had a remarkable effect on the wildlife of the reserve, as G. D. Hayes describes in his article on page 25

NYALA IN THE LENGWE RESERVE IN MALAWI

Plate 6: Two nyala bulls come to join the cows at the waterhole



